\title{
Constant Flood Irrigation (CFI): An Automated Subirrigation System with Individual Supply to Each Container
}

\author{
G.G. Goyette ${ }^{1}$ and W.G. Pill ${ }^{2}$ \\ Delaware Agricultural Experiment Station, Department of Plant and Soil \\ Sciences, College of Agricultural Sciences, University of Delaware, \\ Newark, DE 19717-1303
}

Additional index words. fertigation, microtube irrigation, subsurface irrigation

The constant flood irrigation (CFI) system (Fig. 1) consisted of large saucers that were kept filled with water or fertilizer solution so that growth media in containers standing in the liquid remained at container capacity. Flow of liquid to the saucers through microtube emitters was controlled by an irrigation timer. Compared with the capillary mat irrigation system, the saucer system avoided leachate contamination between pots and provided greater air circulation around containers. Compared with microtube irrigation to the growth medium surface, the saucer system eliminated the need to install or remove microtubes from the growth medium surface and avoided water channelling whereby growth medium directly under the weighted end becomes preferentially wetted.

CFI permitted complete wetting of the growth medium to container capacity irrespective of shrinkage during dehydration. Further requirements of the irrigation system were reduction of leachate loss from the containers, prevention of cross-contamination between containers, and low maintenance.

To provide fertilizer solution or water simultaneously to containers placed anywhere on the bench, the 19-mm-diameter polyethylene (PE) pipe was secured to the mesh bench to form two U-shaped headers with insertells making the comers. A $15-\mathrm{cm}$ section of $\mathrm{PE}$ pipe was connected to the middle of the base of each U-header by means of an inserttee. At the end of this short section was inserted a $19-\mathrm{mm}$ male adapter (insert $\times$ male international pipe thread), which, in turn, was attached to an adapter bushing (19-mm pipe female international pipe thread to $19-\mathrm{mm}$ female garden hose thread). Short sections

Received for publication 25 Mar. 1992. Accepted for publication 8 July 1992. Published as Miscellaneous Paper 1433 of the Delaware Agricultural Experiment Station. Mention of trade names in this publication does not imply endorsement by the Delaware Agricultural Experiment Station of products named-nor criticism of similar ones not mentioned. Contribution 302 of the Plant and Soil Sciences Dept. The cost of publishing this paper was defrayed in part by the payment of page charges. Under postal regulations, this paper therefore must be hereby marked advertisement solely to indicate this fact.

${ }^{1}$ Graduate Research Assistant.

${ }^{2}$ Professor. of standard garden hose connected the PE pipe to both the fertilizer proportioner (MP5 Proportioner, Young Industries, Mountain View, Calif.) and to the dual (Y) valve [19mm-diameter male $\times$ (two) 19-mm-diameter female]. The inflow side of the dual $(\mathrm{Y})$ valve was secured to a disk filter (Amiad U.S.A., Van Nuys, Calif.) containing 80$\mu \mathrm{m}$ (200-mesh) strainers to prevent clogging of the microtubes. A back-flow preventer to prevent contamination of the "fresh water supply was inserted in a short section of garden hose between the inflow side of the disk filter and a battery-operated irrigation timer valve (Melnor Industries, Moonachie, N.J.).

On a $1.7 \times 11-\mathrm{m}$ bench, 120 saucers $(25$ $\mathrm{cm}$ in diameter $\times 3.3 \mathrm{~cm}, 1.8$-liter capacity; Kord Products, Bramalea, Ont.) were arranged evenly to provide $10-\mathrm{cm}$ minimum distance between saucers. Microtubes (1.9 $\mathrm{mm}$ in diameter $\times 76 \mathrm{~cm}$ long; Chapin Watermatics, Watertown, N.Y.) were inserted into punched openings in the headers. Into each saucer were placed the heavy-weight ends of the off-on microtubes, one from the water header and one from the fertilizer solution header. The microtubes connected to the fertilizer solution header were identified with spray paint. Thus, by adjusting the onoff weights, individual containers could receive water or fertilizer solution simultaneously according to any experimental design. By opening and closing the appropriate valves of the dual (Y) valve, all containers could receive either water or fertilizer solution during an irrigation without adjusting the onoff weights. Details regarding microtube irrigation are in Chapin (1980) and Nelson (1991).

Constant liquid level $(3.3 \mathrm{~cm})$ in the saucers was maintained by frequently filling them to overflowing. We selected a four times daily, 15-min irrigation from the 100 watering schedules programmed in the timer. Since a minimum flow rate is required for some proportioners to operate effectively, wasteful overflow could be minimized by installing a timer programmed to deliver high flow rates for short periods (1 to $2 \mathrm{~min}$ ), multiple times each day.

The top of the liquid in the saucer was equivalent to the height of the growth medium-air interface that normally occurs at the bottom of a container. Thus, the satu-

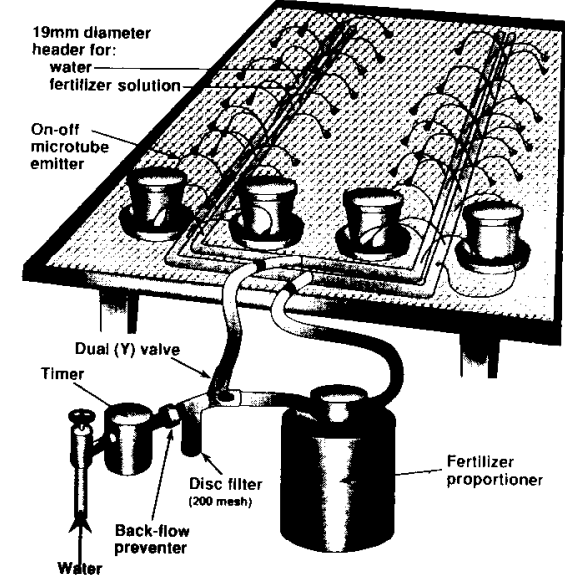

Fig. 1. Schematic diagram of the controlled flood irrigation (CFI) system.

rated zone ("perched water table") was displaced upwards by the height of liquid in the saucer. The matric potential $\left(\psi_{\mathrm{m}}\right)$ in the saturated zone approached $0 \mathrm{MPa}$ but became more negative $(0.0001 \mathrm{MPa} / \mathrm{cm})$ with upward progression within the container to counteract positive gravitational forces (Spomer, 1990). Since the magnitude of capillary rise is inversely proportional to growth medium pore size, the water content at container capacity would be directly proportional to media micropore contents.

CFI supported the growth of pampas grass (Cortaderia selloana Aschers. \& Graebn.) in media of widely different physical properties for 6 months in 3-liter pots with little attention to the irrigation being required other than replacing the fertilizer stock solution in the injector and occasional surface irrigation to lower the soluble salt concentration at the growth medium surface. The liquid-saturated zone deterred root growth, and no roots grew into the liquid-filled saucers.

The major components of the system cost about $\$ 400$ with use of one hundred twenty 1.9-mm heavyweight microtubes.

CFI may be viewed as a modified ebband-flow system (Ball, 1991). Rather than the liquid draining back into a tank following irrigation, the liquid remains in the saucer until capillary rise or evaporation removes it. With fine-tuning to minimize liquid overflow from the saucers, CFI could use less water and fertilizer than conventional irrigation systems.

\section{Literature Cited}

Ball, V. 1991. New irrigation concepts, p. 97122. In: V. Ball (ed.). Ball red book. 15th ed. George Ball Publishing, West Chicago, Ill.

Chapin, R.D. 1980. Drip irrigation, layout and design for greenhouses and nurseries. Chapin Watermatics, Watertown, N.Y.

Nelson, P.V. 1991. Greenhouse operation and management. 4th ed. Prentice Hall, Englewood Cliffs, N.J.

Spomer, L.A. 1990. Evaluating 'drainage' in container and other shallow-drained horticultural soils. Commun. Soil Sci. Plant Anal. 21:221235. 